\title{
PRACTICING ENTREPRENEURIAL LEARNING AS LEARNING METHOD AT MIDDLE SCHOOL STUDENTS
}

\author{
Dwi Sunu Widyo Pebruanto \\ Universitas Ciputra \\ Norashidah Binti Hashim \\ Universiti Utara Malaysia \\ Rosna Bt. Awang Hashim \\ Universiti Utara Malaysia
}

\begin{abstract}
Entrepreneurship education as method needs further exploration in the context of school. Entrepreneurship Center of Ciputra University collaborated with a number of schools in Indonesia developed the K-12, Ciputra Way Learning Cycle. As many as 355 final year students from six schools were involved in this study to gain better understanding towards the factors influencing entrepreneurial competences. Using the method of Structural Equation Model (SEM), result shows that growth orientation, assessment for improvement, positively influence entrepreneurial competences.
\end{abstract}

Keywords: assessment for improvement, entrepreneurial competence, entrepreneurship performance project, feedback seeking, growth orientation, learning engagement

\section{Introduction}

Entrepreneurship education (EE) is recommended to begin with the exploration selfpotential of opportunity recognition, encouraging self-confidence, and dealing with fear of failure (Kelley, Singer \& Herrington, 2011). It is aimed to be an innovative problem solving approach to support "high readiness for change, self-confidence, and creativity" (Heinonen \& Poikkijoki, 2006:81). EE is considered a method to "unleash human potential" (Sarasvathy dan Venkataraman (2010:115) and to enhance the level of competitiveness (Gibb, 2002, 2006, 2011) as well as to develop individual potentials in various parts of professional life through learning process (Jones \& Iredale, 2010, Fayolle and Gailly, 2008). The learning process will be latterly referred as entrepreneurial learning.

*Corresponding Author.

e-mail: dwisunu@ciputra.ac.id
Entrepreneurship as a method offers an opportunity as well as a challenge for entrepreneurship educators to develop a more adaptive entrepreneurial learning model that breaks the constraints of business perspective (Gibb, 2002; Jones \& Iredale, 2010; Pepin, 2012). Entrepreneurial learning outcomes, learning strategies and assessment approach for this context still need further clarification. The explanation of competence as a learning outcome (Jennings, Edwards, Devereaux Jennings, \& Delbridge, 2014), experiential learning as learning strategy (Wing \& Man, 2012), as well as authentic assessment as assessment methods (Neck \& Greene, 2011) still leave a question of how those the components are correlated.

Kolb's experiential learning (C. L. Wang \& Chugh, 2014) and Man's entrepreneurial learning model (Man, 2012) offer a clearer alternative of entrepreneurial learning model. Both proposed the transformational experiences as the basic of learning. However, aspects of stu- 
Cynthia Anggraini \& Tina Melinda / The Effects of Word of Mouth and Sales Promotion on Purchasing Decision for Dreamland Decoration / JEE, Vol. 7, No. 1, March 2018, pp 27-42

dents' context such as perceived autonomy and values as well as learning motivation need to be considered as parts of contributing factors in the process of entrepreneurial learning achievement. Mastery orientation or growth mindset which has been proved to be correlated with students learning achievement (Dweck \& Leggett, 1988; Elliott \& Dweck, 1988; Haimovitz \& Dweck, 2016) need considering to contribute to the formation of entrepreneurial competences.

Another challenge appears from teachinglearning practices. Most of business schools still emphasize on the broadening knowledge and preparing individuals to create a venture and there is only 13 per cent of entrepreneurship courses of are offered as a method, meanwhile in non-business schools, entrepreneurship as a method has not been conducted as part of their course framework. (Pittaway dan Edwards (2012).

University of Ciputra Entrepreneurship Center (UCEC) in Indonesia initiated the development of an entrepreneurial learning model for K-12 learners. It is a cycle of learning model which includes five stages of learning, which are: (1) exploring, stage of facilitating students to build understanding and discover their ideas of innovation; (2) planning, stage of implementing the ideas into a work plan; (3) doing, stage of executing the designed plan; (4) communicating, stage of introducing the outcome to the community; (5) reflecting, stage of measuring the success and identifying possible improvements. However they still fail to convince that their model which widely applied at Indonesian schools does give contribution to the entrepreneurial competences as they expect.

Responding to the shortcomings mentioned, this study is aimed to identify factors influencing entrepreneurial competences among middle school students. By referring to achievement goal theory, especially mastery learning orientation, this study is focused on the influence of growth orientation, entrepreneurial project performance, and perceived assessment for learning towards entrepreneurial competences. By using Ciputra Way Entrepreneurial learning model, the study is aimed to prove that entrepreneurial learning proses, learning growth orientation and assessment for improvement give positive contribution to the entrepreneurial competences.

\section{Entrepreneurial Learning}

A simple explanation of entrepreneurial learning is a mechanism of "what and how individual entrepreneurs learn" (Wang and Chugh, 2014:30). It is a process of generating value (Henry, Hill, \& Leitch, 2005) by practicing or learning by doing which involves emotion and capability (Fiet, 2000; Pepin, 2012), and an experiential interaction between learners and their environment (Corbett, 2005, 2007). It is also grounded by a positive attitude towards the aimed results (Gibb, 2002, 2011) and self-directed learning proses with the aspects of goal setting, self-monitoring, and self-management (Tseng, 20113).

In accordance with the two core processes of entrepreneurship which are exploration and exploitation (Shane \& Venkataraman, 2000), EL involves exploratory learning which is focused on the process of discovery and interpretation to find ideas and to execute them (Wang \& Chugh, 2014). These two processes demand a transformation from action, interaction, or collaboration with various stakeholder (Sarasvathy \& Venkataraman, 2010).

Another essential point is reflection. It is important because learners should be able to internalize the lesson learned as acquired from 
Dwi Sunu Widyo Pebruanto, Norashidah Binti Hashim, Rosna Bt. Awang Hashim / Practicing Entrepreneurial Learning as Learning Method at Middle School Students / JEE, Vol. 7, No. 1, March 2018, pp 27-42

prehension which tends to persist longer rather than the aspect of apprehension, therefore those aspects is considered to be complementary to each other.

EL threats learners as autonomous individuals. They may set up their own learning target as well as monitoring and evaluate their learning process and achievement. Students learn to face the unexpected situations and respond it using their problem solving skills. Learning environment reflects authenticity of the real-world professional situations (Kozkinska, 2011).

\section{Ciputra Way Entrepreneurial Learning (CWEL)}

Ciputra Way Entrepreneurial Learning was designed to facilitate learners to be more entrepreneurial and to emphasize the forming of mindset of thinking and acting entrepreneurially (Ciputra, 2008). This type of learning process is aimed at the development of creativity and innovation skills therefore it will enhance students professional behaviours as well as competitiveness level. Ciputra (2008:83) stated, "I believe that entrepreneurship skill will be highly valuable for any professions. Therefore, spreading entrepreneurship skill will definitely give positive and productive benefit for people". Tanan (as cited in Ciputra, 2008:96) added "We highlight on the construction of particular mindset, character, and skill that will finally lead to the skill to create opportunity to innovate and to calculate risks".

In order to meet the aforementioned expectation, CWEL emphasizes on the enhancement of opportunity recognition capability, creativity development, and innovation, as well as calculated risk taking (UCEC, 2009) which is conducted through 3 main processes including exploration, execution, and reflection. Explora- tion consists of two sub processes which are opportunity and idea exploration as well as planning where ideas are converted into a working plan. Meanwhile, execution consists of doing and communicating. Execution is the stage of planning implementation, while communicating is the stage where students are required to introduce their products or services to a wider community. In the practice, these three processes is manifested into five stages of learning which are conducted to achieve entrepreneurial competence.

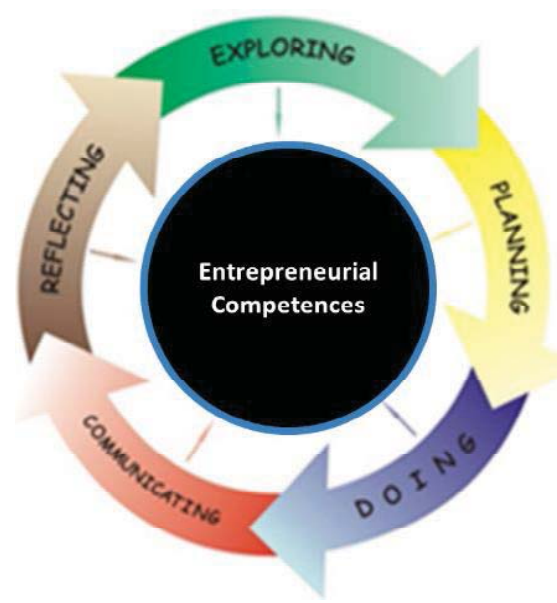

Figur 1 Entrepreneurial Learning, Ciputra Way

\section{Entrepreneurial Competences}

EL is a method to develop individuals who possesses entrepreneurial competences (Gibb, 2002, 2006; 2011; Morris et al., 2013). Competence is described as one's capacity (Winterton, 2009) and capability to accomplish a task in certain field (Danneels, 2002; Rasmussen, Mosey, \& Wright, 2011). While capacity explains the attributes of one's expertise, capability is related to how the expertise is utilized in accomplishing a task (Kakkonen, 2011). It is dynamic, developed by individuals by real experiences in accomplishing tasks (Chell, 2013), and multidimensional which includes behavioral, 
Cynthia Anggraini \& Tina Melinda / The Effects of Word of Mouth and Sales Promotion on Purchasing Decision for Dreamland Decoration / JEE, Vol. 7, No. 1, March 2018, pp 27-42

cognitive, and functional dimensions (Boreham, 2006). Morris, Webb, Fu, dan Singhal (2013) divides competences into two domains which are Behavior Domain (such as opportunity recognition) and attitudinal competences (such as self-efficacy and resilience).

Lans, Biemans, Mulder and V erstegen (2010) suggests that the entrepreneurial competences domains should consist of behavioral and cognitive aspects. Kakkonen (2011) explains that competence is a combination of personality and behavioral perspective which is manifested in the form of knowledge, skill, attitude, and personal qualities.

Parallel with the expectation of Ciputra Way Learning Cycle, this study recommends three competence domains which are the cognitive, the behavior and the attitude. From the list of Morris' Entrepreneurial competences this study selected opportunity recognition and creativity and innovation as the representation of cognitive, networking as the representation of behavior domain, and resilience as the representation of attitude domain. Following is the brief explanation of four aspects of competences as parts of entrepreneurial learning outcomes.

\section{Opportunity Recognition (OR)}

Opportunity recognition (OR) is a momentum of alignment between market needs and the value offered by a creator. The alignment here is about the "fit" or "chance" which entails the three stages of process: (1) developing need perception; (2) discovering need-fulfilment resources; (3) creating a fit and suitable momentum (Ardichvili, Cardozo, \& Ray, 2003). These stages of perception, discovery, and creation are influenced by sensitivity or alertness, prior or background knowledge (Ardichvili et al., 2003; Gaglio \& Katz, 2011), and personal attribution such as creativity (Shane $\&$ Nicolaou, 2014) and image of self (Mitchell \& Shepherd, 2010).

\section{Creativity and Innovation}

Creativity and innovation are crucial in entrepreneurship as both contribute in the process of generating novelty and values. Creativity itself correlates with ideas while innovation is related to novelty or values (Bledow, Frese, Anderson, Erez, \& Farr, 2009). Prior study found that both are correlated in values creation (Baron \& Tang, 2011; Ward, 2004).

Beghetto \& Breslow (2013) classified creativity into three categories: (1) creativity which is related to individual personalities, (2) creativity as a cognitive expression, (3) creativity as the results of interaction process between individual potentials and his environment. This study will highlight particularly the second and third types of creativity. Creativity is habitual meaning it is a means of idea expression through behavior as a form of situational response. Habit is formed as it is reinforced by motivation to improvise and innovate (Glãveanu, 2012). Improvisation is a creative act to solve problems, then again innovation is a creative act based on the awareness to create "a novelty in response to problem" (p.86). With regards to that, novelty is the element which differentiates both. Nevertheless, intentionality and rationality are the common things found in both entities.

In entrepreneurship context, Morris et al (2013) defines creativity and innovation as capability to recognize opportunity which holds possibility to generate novelty and functionality by exploring the relations between different separated things. As it emphasizes on the ability to explore relations, creativity should be in- 
Dwi Sunu Widyo Pebruanto, Norashidah Binti Hashim, Rosna Bt. Awang Hashim / Practicing Entrepreneurial Learning as Learning Method at Middle School Students / JEE, Vol. 7, No. 1, March 2018, pp 27-42

volved through processes of constructing connections to create products or services which possesses the elements of novelty and usefulness.

\section{Networking}

Networking is an individual act to create and to maintain relationship with other stakeholder in order to gain expected benefits (Forret \& Dougherty, 2001; Klerk, 2010). Networking can occur between a number of nodes among individuals, units, or organizations including ventures. Easley \& Kleinberg, (2010) stated that there are three types of motivation to create networking, which are: (1) to explore insights to recognize opportunity; (2) to gain trust; (3) to gain benefit or incentive.

Granovetter (1973) groups social networking as two types of ties in networking including "strong tie" and "weak tie". Strong tie is a type of relationship which is based on emotion and high trust, while "weak tie" is a relationship created by the needs to obtain insight, necessary information, and skills. Some of stakeholders who take parts in forming "strong tie" involves family and friends. Weak tie is formed as a bridge entailing the priory developed strong tie relations (Easley \& Kleinberg, 2010; Grannovetter, 1973).

\section{Resilience}

Resilience is an ability to adapt to achieve outcomes even though it requires efforts in facing any challenges and unexpected risks (Alvord \& Grados, 2005; Masten \& Tellegen, 2012). Studies about resilience posited two perspectives on antecedents, first, the emphasis on individual attribute and ability, while the second view is inclined to the process of adaptation with threatening or challenging conditions. Attribute and ability perspective believes in the process of identifying individual factors while the process perspective is more emphasizes the dynamic interaction between individuals and the emerging challenges (Olsson, Bond, Burns, Vella-Brodrick, \& Sawyer, 2003; Pangallo, Zibarras, Lewis, \& Flaxman, 2015).

In learning context, resilience is defined as the success of achieving learning outcomes despite the unsupportive environmental condition (Ricketts, Engelhard Jr., \& Chang, 2015). Concurrently, resilience here refers to the conception of "daily resilience" or "buoyancy" which is the aptitude to adapt with difficult situations encountered in daily life, such as academic risks or possibility of failure either in achieving learning outcomes or tasks accomplishment (Martin, Ginns, Brackett, Malmberg, \& Hall, 2013; Martin \& Marsh, 2008). The difference between resilience and buoyancy is on the level of the risks. Resilience is conceived as having greater risk factors rather than buoyancy (Alvord \& Grados, 2005).

\section{Growth Orientation}

Growth orientation is an openness towards challenges and orientation of capability development (Dweck \& Leggett, 1988; Elliott \& Dweck, 1988). Individuals with Growth Orientation is suggested to engage better in task accomplishments (Levy-Tossman, Kaplan, \& Assor, 2007), to possess high self-efficacy (Komarraju \& Nadler, 2013), to perceive that skills can be developed and is not static (Dweck, 2015; Yeager, Dweck, \& Yeager, 2012). Elliot dan McGregor (2001) classified the development into three categories including development based on pre-determined task criterion (task approach), development based on indi- 
Cynthia Anggraini \& Tina Melinda / The Effects of Word of Mouth and Sales Promotion on Purchasing Decision for Dreamland Decoration / JEE, Vol. 7, No. 1, March 2018, pp 27-42

vidual's previous achievement (intrapersonal approach), and development based on others' achievement (normative).

Growth orientation is predicted to potentially affect the enhancement of Entrepreneurial Competences. In other words, Entrepreneurial Competences is expected to grow when individuals have the genuine willingness to direct their self-development to acquire better competences.

\section{Assessment for Improvement}

Assessment could be a stimulus for individuals to cultivate intrinsic motivation to accomplish the given tasks (Weurlander, Söderberg, Scheja, Hult, \& Wernerson, 2012). Assessment for learning is also functioned as the feedback to achieve betterment in learning strategy (Brown, 2011) which may impact the students' accountability (Brown \& Hirschfeld, 2007, 2008). Clark (2012) differentiate assessment into assessment as the identification of gap between the temporary condition and the expected result (assessment as gap), and the assessment as reflection based on the existing proofs (assessment as learning). Both should be conducted continuously during the learning process therefore it is possible to identify the improvement and the necessary step to take.

It is important to synchronize the learning instruction and assessment, as well as to ensure the conduct of authentic assessment by creating the fidelity of the assessment situation compared to the real condition (Bastiaens \& Kirschner, 2004). According to the same authors, there are five dimensions of Authentic Assessment: (1) task completion which requires integration of knowledge, skill, and attitude; (2) fidelity with real context in the professional world; (3) facilitation of collaboration and indi- vidual tasks; (4) product outcomes which represent the mastery of competence, and (5) standard and criterion which equates the real professional context.

The determined criteria also should be the reference for students to measure their own competence as it is capable to present the big picture of each individual's uniqueness through the various authentic evidences it records (Lans et al., 2010). Criteria becomes an "end-in-view" (Pepin, 2012: 806) in which students can attain the reflection before deciding the next entrepreneurial act.

\section{Entrepreneurial Performance}

Entrepreneurial performance is often times associated with what is resulted by individuals, teams, or firms (Agbim, Oriare, \& Zever, 2014; Hsu, Tan, Laosirihongthong, \& Leong, 2011; Kollmann \& Stöckmann, 2012; Zhou \& Rosini, 2015). The outcome could be in the form of profit, incomes or the growth of the company (Casillas \& Moreno, 2010), or a novel product or process (Kumar \& Jagacinski, 2011). Moreover, Yusuf (2010) wrote that "growth, profitability and survival, for example, are some of the more popular measures of entrepreneurial outcomes that have been used" (p. 329).

Entrepreneurial Performance in business is inclined to the financial performance context. However this parameter has posed a problem when adapted into the context of entrepreneurship education where business process is only situated as the means to develop the entrepreneurial competence of the students. In regards to that concerns, in this context, the forming of Entrepreneurial Performance should be viewed with a multiperspective approach. Accordingly, this present study uses two approaches of entrepreneurial performance which is based on 
Dwi Sunu Widyo Pebruanto, Norashidah Binti Hashim, Rosna Bt. Awang Hashim / Practicing Entrepreneurial Learning as Learning Method at Middle School Students / JEE, Vol. 7, No. 1, March 2018, pp 27-42

the perspective of Learning Motivation, specifically the Achievement Goal Theory and Competence-based.

Achievement Goal Theory explains that Performance Goal is related to the efforts given to demonstrate competence (A. J. Elliot, Murayama, \& Pekrun, 2011) as well as the social comparison and recognition (Darnon, Dompnier, Gilliéron, \& Butera, 2010). Goal becomes an important element which determines an individual's orientation towards certain objectives. Mastery orientation is focused on the efforts to enhance competence while performance orientation is related to the willingness to achieve certain results or acknowledgment from others.

Entrepreneurial performance in this research refers to the outcomes of students' entrepreneurial projects which are facilitated to be exhibited therefore it would gain recognition from others. The performance approach is expected to be fairly implemented to the students learning process of becoming more entrepreneurial and subsequently will result in the performance which suits their context.

\section{Entrepreneurial Competences}

Competence describes the explanation one's capacity (Winterton, 2009) and capability to accomplish a task in certain field (Danneels, 2002; Rasmussen et al., 2011). While capacity explains the attributes of one's expertise, capability is related to how the expertise is utilized in accomplishing a task.

Competence is dynamic, developed by individuals by real experiences in accomplishing tasks (Chell, 2013), and it is multidimensional which includes behavioral, cognitive, and functional dimensions (Boreham, 2006). Morris, Webb, Fu, dan Singhal (2013) divides competences into two domains which are Behavior
Domain (such as opportunity recognition) and attitudinal competences (such as self-efficacy and resilience). Lans, Biemans, Mulder and Verstegen (2010) suggests that behavioral aspect and cognitive aspect as the domains of entrepreneurial competences. Kakkonen (2011) explains that competence is a combination of personality and behavioral perspective which is manifested in the form of knowledge, skill, attitude, and personal qualities.

Parallel with the expectation of Ciputra Way Learning Cycle, this study recommends three competence domains. First, the domain of knowledge and mindset which manifest the cognitive. The next domain is behavior which manifests skills. Lastly, the domain of attitude. Entrepreneurial competence domains as suggested by Morris were selected to represent the aforementioned three domains, including opportunity recognition also creativity and innovation as representation of cognitive, networking as representation of behavior domain, and Resilience as representation of attitude domain.

\section{Method}

Population involved in this research are secondary and high school students from a number of schools under The Foundation of Ciputra Entrepreneurship. The inclusive criteria of the chosen schools are: 1) Cooperate with the Ciputra Foundation; 2) Teachers in the referred schools has acquired training by The Ciputra Foundation; 3) The school consistently implement teaching using the K-12 model, Ciputra Way. The sample in this study are the final year students from each school. The final year student is selected as they have possessed learning experiences and adequate perception toward entrepreneurship during their three years of study which possibly will be continued in 
Cynthia Anggraini \& Tina Melinda / The Effects of Word of Mouth and Sales Promotion on Purchasing Decision for Dreamland Decoration / JEE, Vol. 7, No. 1, March 2018, pp 27-42

high school meaning those students will also have the option to continue their current project. Sampling method used in this study was purposive sampling with the number of 355 participants. Table 1 illustrates the detail of sampling figure in each school.

Table 1 Sample Distribution

\begin{tabular}{lc}
\hline \multicolumn{1}{c}{ School } & Sample \\
\hline Sekolah Ciputra, Surabaya, East Java & 67 \\
Sekolah Citra Berkat Bukit Palma, Surabaya, East Java & 61 \\
Sekolah Citra Berkat Taman Dayu, East Java & 11 \\
Sekolah Citra Kasih Jakarta & 86 \\
Sekolah Citra Berkat, Tangerang, West Java & 74 \\
Sekolah Tunas Daud Denpasar, Bali & 56 \\
Total & 355 \\
\hline
\end{tabular}

Growth Orientation was measured using the adapted questionnaire from Midgley, et al. (2000), while Assessment was measured by adapting the questionnaire from Brown, Irving, Peterson and Hirschfeld (2009). Each measurement provides five-point range of responses between 1 (totally disagree) to 5 (totally agree). Whereas Entrepreneurial Competence was measured by the teachers' assessment which was determined by competence achievement and entrepreneurial project performance as attained by the students' final project marks. Both assessment were conducted according to the designated rubric which was created to help teachers in making the grading decision. The final score can be given in the marking was classified into five-point range from 1 to 5 .

All the questionnaires were adapted and adjusted with the K-12 learning model, Ciputra Way, and translated into Bahasa Indonesia. The adapted questionnaires also have been evaluated by using experts judgement (school counselor, education psychologist, and linguist) as well as consulted to the students themselves in regards to the language and consideration of the adaptation. Afterwards, validity test was conducted using confirmatory factor analysis, followed by the reliability testing using the Alpha Cronbach analysis with 30 persons of the sample. Final analysis conducted was the hypothesis testing by using the Structural Equation Modeling (SEM).

To prove the reliability of each measurement, Alpha Cronbach Analysis was conducted. Furthermore, Confirmatory Factor Analysis was also conducted to attain the validity of each instrument. Table 2 depicts the results of reliability testing.

Table 2 Reliability Analysis

\begin{tabular}{lccc}
\hline \multicolumn{1}{c}{ Variable } & $\begin{array}{c}\text { Number of } \\
\text { Items }\end{array}$ & $\begin{array}{c}\text { Alpha } \\
\text { Cronbach }\end{array}$ & CITC \\
\hline Growth Orientation & 3 & 0,778 & $0,351-0,441$ \\
Assessment for Improvement & 3 & 0,817 & $0,643-0.697$ \\
\hline
\end{tabular}

According to Table 2, it can be concluded that the measurement of Growth Orientation is both reliable and valid as it is evident that the Alpha Cronbach of the questionnaire surpasses the cut-off point of 0,7 with all CITC value of the items higher than 0.3. Likewise, the instrument of Assessment of Improvement also shows good reliability with the number of Alpha Cronbach as high as $0.817(\alpha \geq 0,7)$, with CITC value of all item exceeds the cut-off point of 0.3 .

Table 3 Confirmatory Factor Analysis

\begin{tabular}{llrccc}
\hline \multicolumn{1}{c}{ Variable } & Items & $\begin{array}{c}\text { Factor } \\
\text { Loading }\end{array}$ & Conclusion & CR & AVE \\
\hline \multirow{2}{*}{ Growth } & GO1 & 0,724 & Valid & & \\
Orientation & GO2 & 0,816 & Valid & 0,79 & 0,55 \\
& GO3 & 0,663 & Valid & & \\
Assessment for & Ass_Imp1 & 0,801 & Valid & & \\
Improvement & Ass_Imp2 & 0,747 & Valid & 0,82 & 0,60 \\
& Ass_Imp3 & 0,768 & Valid & & \\
\hline
\end{tabular}


Dwi Sunu Widyo Pebruanto, Norashidah Binti Hashim, Rosna Bt. Awang Hashim / Practicing Entrepreneurial Learning as Learning Method at Middle School Students / JEE, Vol. 7, No. 1, March 2018, pp 27-42

Following the reliability testing is Confirmatory Factor Analysis (CFA). Table 3 provides the results of CFA of each variable.

According to the CFA, results show that all the items possess factor loading value higher than 0.4 , ranging from 0.6634 to 0.816 . Therefore, it can be concluded that all of the items are valid. The CR value obtained were 0.79 and 0.82 with the values of AVE of 0.55 and 0.60 .

\section{Results}

Entrepreneurial project performance itself positively influences entrepreneurial competence as high as 78.2\%. Besides, Growth Orientation and Assessment also positively affects Entrepreneurial Project Performance as much as $7.5 \%$ and $8.1 \%$ respectively. Consequently, it can be concluded that entrepreneurial competence is more influenced by entrepreneurial project performance. The model testing shows goodness of fit with $\chi^{2}$ as high as 66.694 ; with the p-value of 0.346; RMSEA as high as 0.013; GFI as high as 0,976 ; AGFI value of 0,951 ; NFI value of 0,976 ; TLI value of 0,997 ; dan CFI value of $0,999(p$ value $\geq 0,05$; RMSEA $\leq 0,05$; GFI $\geq 0,90$; AGFI $\geq 0,90$; NFI $\geq 0,90$; TLI $\geq 0,90$; CFI $\geq 0,97$ ).

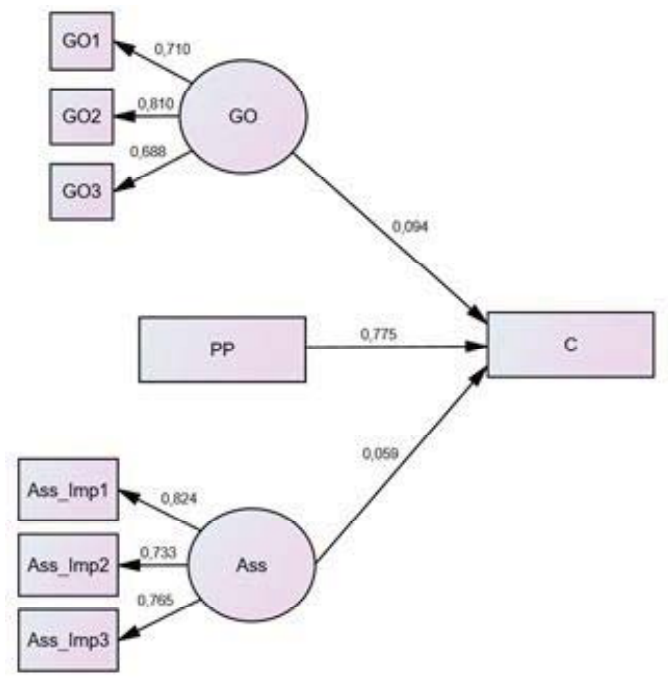

Figur 2 Conceptual Model

\section{Discussion}

As predicted, Entrepreneurial Project Performance as encouraged through Ciputra Way Learning Cycle Model as the method, influence the final outcomes of learning which Entrepreneurial Competence is. This finding contributes in enriching the various process carried out in entrepreneurship education. In the previous studies, entrepreneurship education was found impacting the development of cognition, such as creativity (Athayde, 2012), attitude, self-efficacy, proactiveness, and risk taking (Sanchez, 2013). It is also discovered as an impactful factor towards personal and social behaviours of students such as civic skill and cultural awareness(Paço, Ferreira, Raposo, Rodrigues, \& Dinis, 2011). Through this present study, Ciputra-Way Learning Cycle Model is proven contributing to the three dimensions of competence which are cognitive (opportunity recognition as well as creativity and innovation), behavioral (networking), and attitudinal dimensions (resilience).

Growth Orientation which is adapted from the concept of Mastery Orientation also shows possibility to be accommodated in the process of entrepreneurial learning. Growth Orientation prevents students from learning which merely aimed at grade attainment, in contrast, it encourages competition and competitiveness. The orientation has made learning become a process of constructing a learning culture (Dweck, 2015) and strengthen resilience in entrepreneurial learning (Yeager et al., 2012). Growth Orientation is manifested into the final outcome in the form of designated competence objectives which are aimed to facilitate development of students' positive efficacy towards their entrepreneurial projects (Blackwell \& 
Cynthia Anggraini \& Tina Melinda / The Effects of Word of Mouth and Sales Promotion on Purchasing Decision for Dreamland Decoration / JEE, Vol. 7, No. 1, March 2018, pp 27-42

Trzesniewski, 2007)(Blackwell \& Trzesniewski, 2007).

Furthermore, this study also confirms that Assessment for Improvement possess an essential role towards achievement. Through assessment, students acquire feedback regarding their learning improvement (Solomonidou \& Michaelides, 2017). Assessment becomes a process of information seeking where students can obtain the understanding of their temporary condition and the development target they should achieve further. With the role of assessment as feedback, Ciputra-Way Learning Cycle Model promises potential to construct the self-regulated behavior also develop responsibility as well as the betterment of students learning outcome (Brown, 2011; Brown \& Hirschfeld, 2007). Criterion-based assessment as implement is perceived to help student in developing their learning process experience. Despite the fact that this research only covered the discourse of Assessment for Improvement and has not included the aspect of accountability, however the findings suggests possibility of criterion-based formative assessment model. Another thing to put into account is assessment should not be a strict control system whch constrains the students autonomy (Z. Wang \& Brown, 2014).

\section{Suggestions}

This study considers entrepreneurial competences as unidimension, subsequently, it still is unable to reveal the role of possible antecedents of each competence. Future research is suggested to include and test the antecedents of each type of entrepreneurial competences as it is conceived will present flexibility in analyzing different sub-dimension of competence.

Another limitation of this study is that it solely includes growth orientation without con- sidering performance orientation or multiple goal orientation (Pintrich et al., 2000). In order to proceed an entrepreneurial learning particularly which utilizes project as means of learning might need these two types of orientation. Multiple goal orientation is expected to give students the sense of target emphasis in each stage of learning cycle. Whilst, performance orientation might be related with the success of entrepreneurial project performance.

Furthermore, future research should better consider task perceived values as learners subjective emotion is expected as taking parts in the process of experiential learning. Another variable to put into account is assessment strategy as some strategies such as self-assessment and peer-assessment possibly gives a good reflection of the development of self-regulated learning among students.

\section{References}

Agbim, K.C., Oriare, G., \& Zever, T. A. 2014. Moderating Effects of Individual Entrepreneur and Enterprise Characteristics on the Relationship between Business Environmental Scanning Behaviour and Entrepreneurial Performance. Journal of Business Studies Quarterly, 6(1), 248-268.

Alvord, M.K. \& Grados, J. J. 2005. Enhancing Resilience in Children: A Proactive Approach. Professional Psychology: Research and Practice, 36(3), 238-245. https:// doi.org/10.1037/0735-7028.36.3.238

Ardichvili, A., Cardozo, R., \& Ray, S. 2003. A Theory of Entrepreneurial Opportunity Identification and Development. Journal of Business Venturing, 18(1), 105-123. https://doi.org/10.1016/S0883-9026(01) 00068-4 
Dwi Sunu Widyo Pebruanto, Norashidah Binti Hashim, Rosna Bt. Awang Hashim / Practicing Entrepreneurial Learning as Learning Method at Middle School Students / JEE, Vol. 7, No. 1, March 2018, pp 27-42

Athayde, R. 2012. The Impact of Enterprise Education on Attitudes to Enterprise in Young People: an Evaluation Study. Education + Training, 54(8), 709-726. https:/ /doi.org/10.1108/00400911211274846

Baron, R.A. \& Tang, J. 2011. The Role of Entrepreneurs in Firm-Level Innovation: Joint Effects of Positive Affect, Creativity, and Environmental Dynamism. Journal of Business Venturing, 26(1), 49-60. https:// doi.org/10.1016/j.jbusvent.2009.06.002

Bastiaens, T.J., \& Kirschner, P.A. 2004. A FiveDimensional Framework for Authentic Assessment. Educational Technology Research and Development, 52(3), 67-86.

Beghetto, R.A. \& Breslow, J.Z. 2013. A Commanding Survey of the Creativity Studies Landscape: a Review of Explaining Creativity: the Science of Human Innovation (2nd ed.). Psychology of Aesthetics, Creativity, and the Arts, 7(4), 417-418. https:/ /doi.org/10.1037/a0033310

Blackwell, L.S. \& Trzesniewski, K.H. 2007. Implicit Theories of Intelligence Predict Achievement across an Adolescent Transition/ : A Longitudinal Study and an Intervention Author (s): Lisa S . Blackwell, Kali H . Trzesniewski and Carol Sorich Dweck Published by: Wiley on behalf of the Society. Child Development, 78(1), 246-263.

Bledow, R., Frese, M., Anderson, N., Erez, M., \& Farr, J. 2009. A Dialectic Perspective on Innovation: Conflicting Demands, Multiple Pathways, and Ambidexterity. Industrial and Organizational Psychology, 2(3), 305-337. https://doi.org/10.1111/j. 1754-9434.2009.01154.x

Boreham, N. 2006). The Co-Construction of Individual and Organizational Competence in Learning. Educational Research.
Brown, G.T.L. 2011. Self-Regulation of Assessment Beliefs and Attitudes: a Review of the Students' Conceptions of Assessment Inventory. Educational Psychology, 31(October 2014), 731-748. https://doi.org/ 10.1080/01443410.2011.599836

Brown, G.T.L. \& Hirschfeld, G.H.F. 2007. Students' Conceptions of Assessment and Mathematics: Self-Regulation Raises Achievement 1. Australian Journal of Educational Developmental Psychology, 7, 6374.

Brown, G.T.L. \& Hirschfeld, G.H.F. 2008. Students' Conceptions of Assessment: Links to Outcomes. Assessment in Education: Principles, Policy \& Practice, 15(1), 3-17. https://doi.org/10.1080/0969594070187 6003

Brown, G.T.L., Irving, S.E., Peterson, E.R., \& Hirschfeld, G.H.F. 2009. Use of Interactive-Informal Assessment Practices: New Zealand Secondary Students' Conceptions of Assessment. Learning and Instruction, 19(2), 97-111. https://doi.org/10.1016/ j.learninstruc.2008.02.003

Casillas, J.C. \& Moreno, A.M. 2010. The Relationship between Entrepreneurial Orientation and Growth: The Moderating Role of Family Involvement. Entrepreneurship \& Regional Development, 22(3-4), 265-291. https://doi.org/10.1080/0898 5621003726135

Chell, E. 2013. Review of Skill and the Entrepreneurial Process. International Journal of Entrepreneurial Behaviour \& Research, 19(1), 6-31. https://doi.org/10.1108/13552 551311299233

Corbett, A.C. 2005. Experiential Learning within the Process of Opportunity Identification and Exploitation. Corbett, Andrew C., (July), 473-491. 
Cynthia Anggraini \& Tina Melinda / The Effects of Word of Mouth and Sales Promotion on Purchasing Decision for Dreamland Decoration / JEE, Vol. 7, No. 1, March 2018, pp 27-42

Corbett, A. C. 2007. Learning Asymmetries and the Discovery of Entrepreneurial opportunities. Journal of Business Venturing, 22(1), 97-118. https://doi.org/10.1016/ j.jbusvent.2005.10.001

Danneels, E. 2002. The Dynamics of Product Innovation and Firm Competences. Strategic Management Journal, 23(12), 10951121. https://doi.org/10.1002/smj.275

Darnon, C., Dompnier, B., Gilliéron, O., \& Butera, F. 2010. The Interplay of Mastery and Performance Goals in Social Comparison: a Multiple-Goal Perspective. Journal of Educational Psychology, 102(1), 212222. https://doi.org/10.1037/a0018161

Dweck, C.S. 2015. Growth. British Journal of Educational Psychology, 85, 242-245. https://doi.org/10.1111/bjep.12072

Dweck, C.S. \& Leggett, E.L. 1988. A SocialCognitive Approach to Motivation and Personality. Psychological Review, 95(2), 256-273. https://doi.org/10.1037//0033295X.95.2.256

Easley, D. \& Kleinberg, J. 2010. Strong and Weak Ties. Networks, Crowds, and Markets: Reasoning about a Highly Connected World.

Elliot, A.J., \& McGregor, H.A. 2001. A 2 X 2 Achievement Goal Framework. Journal of Personality and Social Psychology, 80(3), 501-19.

Elliot, A.J. Murayama, K., \& Pekrun, R. 2011. A $3 \times 2$ Achievement Goal Model. Journal of Educational Psychology, 103(3), 632648. https://doi.org/10.1037/a0023952

Elliott, E.S. \& Dweck, C.S. 1988. Goals: an Approach to Motivation and Achievement. Journal of Personality and Social Psychology, 54(1), 5-12.

Fayolle, A. \& Gailly, B. 2008. From Craft to Science: Teaching Models and Learning Processes in Entrepreneurship Education.
Journal of European Industrial Training, 32(7), 569-593. https://doi.org/10.1108/ 03090590810899838

Fiet, J.O. 2000. The Pedagogical Side of Entrepreneurship Theory. Journal of Business Venturing, 9026(16), 101-117.

Forret, M.L. \& Dougherty, T.W. 2001. Correlates of Networking Behavior for Managerial and Professional Employees. Group \& Organization Management, 26, 283311. https://doi.org/10.1177/10596011 01263004

Gaglio, C.M. \& Katz, J.A. 2011. The Psychological Basis of Identification/ : Opportunity Alertness Entrepreneurial. Small Business Economics, 16(2), 95-111.

Gibb, A. 2002. In Pursuit of a New "Enterprise" and "Entrepreneurship" Paradigm for Learning: Creative Destruction, New Values, New Ways of Doing Things and New Combinations of Knowledge. International Journal of Management Reviews, 4(3), 233-269. https://doi.org/10.1111/ 1468-2370.00086

Gibb, A. 2006. Entrepreneurship: Unique Solutions for Unique Environments Is it possible to Achieve this with the Existing Paradigm? In International Council for Small Business World Conference (Vol. 44, pp. 1-41). Mebourne.

Gibb, A. 2011. Concepts into Practice: Meeting the Challenge of Development of Entrepreneurship Educators around an Innovative Paradigm: The Case of the International Entrepreneurship Educators' Programme (IEEP). International Journal of Entrepreneurial Behaviour \& Research, 17(2), 146-165. https://doi.org/10.1108/ 13552551111114914

Glãveanu, V.P. 2012. Habitual Creativity: Revising Habit, Reconceptualizing Creativity. 
Dwi Sunu Widyo Pebruanto, Norashidah Binti Hashim, Rosna Bt. Awang Hashim / Practicing Entrepreneurial Learning as Learning Method at Middle School Students / JEE, Vol. 7, No. 1, March 2018, pp 27-42

Review of General Psychology, 16(1), 7892. https://doi.org/10.1037/a0026611

Grannovetter, M.S. 1973. The Strength of Weak Ties. The American Journal of Sociology, 78(6), 1360-1380.

Haimovitz, K. \& Dweck, C.S. 2016. What Predicts Children's Fixed and Growth Intelligence Mind-Sets? Not Their Parents' Views of Intelligence but Their Parents' Views of Failure. Psychological Science, 27(6), 856-859. https://doi.org/10. $1177 / 0956797616639727$

Heinonen, J. \& Poikkijoki, S.A. 2006. An Entrepreneurial-Directed Approach to Entrepreneurship Education: Mission Impossible? Journal of Management Development, 25(1), 80-94. https://doi.org/10. 1108/02621710610637981

Henry, C., Hill, F., \& Leitch, C. 2005. Entrepreneurship Education and Training: Can Entrepreneurship be Taught? Part II. Education + Training, 47(3), 158-169. https:/ /doi.org/10.1108/00400910510592211

Hsu, C.C., Tan, K.C., Laosirihongthong, T., \& Leong, G.K. 2011. Entrepreneurial SCM Competence and Performance of Manufacturing SMEs. International Journal of Production Research, 49(22), 6629-6649. https://doi.org/10.1080/00207543.2010. 537384

Jennings, J.E., Edwards, T., Devereaux Jennings, P., \& Delbridge, R. 2014. Emotional Arousal and Entrepreneurial Outcomes: Combining Qualitative Methods to Elaborate Theory. Journal of Business Venturing, 30 (1), 113-130. https://doi.org/10.1016/j. jbusvent.2014.06.005

Jones, B. \& Iredale, N. 2010. Enterprise Education as Pedagogy. Education + Training, 52(1), 7-19. https://doi.org/10.1108/004 00911011017654
Kakkonen, M.L. 2011. Students' Perceptions of Their Business Competences and Entrepreneurial Intention. Management, 6(3), 225-243.

Kelley, D. J., Singer, S., \& Herrington, M. (2011). The Global Entrepreneurship Monitor 2011 Global Report.

Klerk, S.De. 2010. The Importance of Networking as a Management Skill. South African Journal of Business Management, 41(1), 37-50.

Kollmann, T. \& Stöckmann, C. 2012. Filling the Entrepreneurial Orientation-Performance Gap: The Mediating Effects of Exploratory and Exploitative Innovations. Entrepreneurship: Theory and Practice, 1001-1027. https://doi.org/10.1111/j. 1540-6520.2012.00530.x

Komarraju, M. \& Nadler, D. 2013. Self-Efficacy and Academic Achievement: Why Do Implicit Beliefs, Goals, and Effort Regulation. Learning and Individual Differences, 25, 67-72. https://doi.org/10. 1016/j.lindif.2013.01.005

Kozkinska, I. 2011. Contemporary Approaches to Entrepreneurship Education Inna Kozlinska. Journal of Business Management, (4), 205-220.

Kumar, S. \& Jagacinski, C.M. 2011. Confronting Task Difficulty in Ego Involvement: Change in Performance Goals. Journal of Educational Psychology, 103(3), 664-682. https://doi.org/10.1037/a0023336

Lans, T., Biemans, H., Mulder, M., \& Verstegen, J. 2010. Self-Awareness of Mastery and Improvability of Entrepreneurial Competence in Small Businesses in the Agrifood Sector. Human Resource Development Quarterly, 21(2), 147-169. https://doi.org/ $10.1002 / \mathrm{hrdq}$ 
Cynthia Anggraini \& Tina Melinda / The Effects of Word of Mouth and Sales Promotion on Purchasing Decision for Dreamland Decoration / JEE, Vol. 7, No. 1, March 2018, pp 27-42

Levy-Tossman, I., Kaplan, A., \& Assor, A. 2007. Academic Goal Orientations, Multiple Goal Profiles, and Friendship Intimacy among Early Adolescents. Contemporary Educational Psychology, 32(2), 231-252. https://doi.org/10.1016/j.cedpsych.2006. 06.001

Martin, A.J., Ginns, P., Brackett, M.A., Malmberg, L.E., \& Hall, J. 2013. Academic Buoyancy and Psychological Risk: Exploring Reciprocal Relationships. Learning and Individual Differences, 27, 128-133. https: //doi.org/10.1016/j.lindif.2013.06.006

Martin, A.J. \& Marsh, H.W. (2008). Academic buoyancy: Towards an Understanding of Students' Everyday Academic Resilience. Journal of School Psychology, 46(1), 5383. https://doi.org/10.1016/j.jsp.2007.01. 002

Masten, A.S. \& Tellegen, A. 2012. Resilience in Developmental Psychopathology: Contributions of the Project Competence Longitudinal Study. Development and Psychopathology, 24(02), 345-361. https://doi. org/10.1017/S095457941200003X

Mitchell, J.R., \& Shepherd, D.A. 2010. To Think Own Self be True: Images of Self, Images of Opportunity, and Entrepreneurial Action. Journal of Business Venturing, 25(1), 138-154. https://doi.org/10.1016/ j.jbusvent.2008.08.001

Morris, M.H., Webb, J.W., Fu, J., \& Singhal, S. 2013. A Competency-Based Perspective on Entrepreneurship Education: Conceptual and Empirical Insights. Journal of Small Business Management, 51(3), 352369. https://doi.org/10.1111/jsbm.12023

Mueller, S., \& Anderson, A. R. (2014). Understanding the Entrepreneurial Learning Process and Its Impact on Students' Personal
Development: a European Perspective. International Journal of Management Education, 44, 1-12. https://doi.org/10.1016/ j.ijme.2014.05.003

Neck, H.M., \& Greene, P.G. 2011. Entrepreneurship Education: Known Worlds. Journal of Small Business Management 2011, 49(1), 55-70.

Olsson, C.A., Bond, L., Burns, J.M., VellaBrodrick, D.A., \& Sawyer, S.M. 2003. Adolescent Resilience: a Concept Analysis. Journal of Adolescence, 26(1), 1-11. https://doi.org/10.1016/S0140-1971(02) 00118-5

Paço, A.M.F., Ferreira, J.M., Raposo, M., Rodrigues, R.G., \& Dinis, A. 2011. Behaviours and Entrepreneurial Intention: Empirical Findings about Secondary Students. Journal of International Entrepreneurship, 9(1), 20-38. https://doi.org/10. 1007/s10843-010-0071-9

Pangallo, A., Zibarras, L., Lewis, R., \& Flaxman, P. 2015. Resilience Through the Lens of Interactionism: a Systematic Review. Psychological Assessment, 27(1), 1-20. https:/ /doi.org/10.1037/pas0000024

Pepin, M. 2012. Enterprise Education: a Deweyan Perspective. Education + Training, 54(8), 801-812. https://doi.org/10.1108/ 00400911211274891

Pintrich, P.R., Elder, A.D., Garcia, T., Anderman, L.H., Hofer, B., Patrick, H., \& Urdan, T. 2000. Multiple Goals, Multiple Pathways: The Role of Goal Orientation in Learning and Achievement, 92(3), 544-555.

Pittaway, L. \& Edwards, C. 2012. Assessment: Examining Practice in Entrepreneurship Education. Education + Training, 54(8), 778-800. https://doi.org/10.1108/004009 11211274882 
Dwi Sunu Widyo Pebruanto, Norashidah Binti Hashim, Rosna Bt. Awang Hashim / Practicing Entrepreneurial Learning as Learning Method at Middle School Students / JEE, Vol. 7, No. 1, March 2018, pp 27-42

Rasmussen, E., Mosey, S., \& Wright, M. 2011. The Evolution of Entrepreneurial Competencies: A Longitudinal Study of University Spin-Off Venture Emergence. Journal of Management Studies, 48(6), 1314-1345. https://doi.org/10.1111/j.1467-6486.2010. 00995.x

Ricketts, S.N., Engelhard Jr., G., \& Chang, M.L. 2015. Development and Validation of a Scale to Measure Academic Resilience in Mathematics. European Journal of Psychological Assessment, No Pagination Specified. https://doi.org/10.1027/10155759/a000274

Sanchez, J.C. 2013. The Impact of an Entrepreneurship Education Program on Entrepreneurial Competencies and ... Journal of Small Business Management, 51(3), 447465. https://doi.org/10.1111/jsbm.12025

Sarasvathy, S.D. \& Venkataraman, S. 2010. Entrepreneurship as Method: Open Questions for an Entrepreneurial Future. Entrepreneurship: Theory \& Practice, 113135. https://doi.org/10.1111/j.1540-6520. 2010.00425.x

Shane, S. \& Nicolaou, N. 2014. Creative Personality, Opportunity Recognition and the Tendency to Start Businesses: a Study of Their Genetic Predispositions. Journal of Business Venturing, Article in. https:// doi.org/10.1016/j.jbusvent.2014.04.001

Shane, S. \& Venkataraman, S. 2000. The Promise of Entrepreneurship as a Field of Research. Academy of Management Review, 25(1), 217-227.

Solomonidou, G. \& Michaelides, M. 2017. Students' Conceptions of Assessment Purposes in a Low Stakes Secondary-School Context: a Mixed Methodology Approach. Studies in Educational Evaluation, 52, 35-
41. https://doi.org/10.1016/j.stueduc.2016. 12.001

Tseng, C.C. 2013. Connecting Self-Directed Learning with Entrepreneurial Learning to Entrepreneurial Performance. International Journal of Entrepreneurial Behaviour \& Research, 19(4), 425-446.

Wang, C.L. \& Chugh, H. 2014. Entrepreneurial Learning: Past Research and Future Challenges. International Journal of Management Reviews, 16(1), 24-61. https://doi. org/10.1111/ijmr.12007

Wang, Z., \& Brown, G.T.L. 2014. Higher Education Research \& Development Hong Kong Tertiary Students' Conceptions of Assessment of Academic Ability. Higher Education Research \& Development, 33 (5), 1063-1077. https://doi.org/10.1080/ 07294360.2014 .890565

Ward, T.B. 2004. Cognition, Creativity, and Entrepreneurship. Journal of Business Venturing, 19(2), 173-188. https://doi.org/10. 1016/S0883-9026(03)00005-3

Weurlander, M., Söderberg, M., Scheja, M., Hult, H., \& Wernerson, A. 2012. Exploring Formative Assessment as a Tool for Learning: Students' Experiences of Different Methods of Formative Assessment. Assessment \& Evaluation in Higher Education, 37(6), 747-760. https://doi.org/ 10.1080/02602938.2011.572153

Wing, T. \& Man, Y. 2012. Developing a Behaviour-Centred Model of Entrepreneurial Learning. Journal of Small Business and Enterprise Development, 19(3), 549-566. https://doi.org/10.1108/14626001211250 289

Winterton, J. 2009. Competence across Europe: Highest Common Factor or Lowest Common Denominator? Journal of Euro- 
Cynthia Anggraini \& Tina Melinda / The Effects of Word of Mouth and Sales Promotion on Purchasing Decision for Dreamland Decoration / JEE, Vol. 7, No. 1, March 2018, pp 27-42

pean Industrial Training, 33(8/9), 681-700. https://doi.org/10.1108/0309059091099 3571

Yeager, D.S., Dweck, C.S., \& Yeager, D.S. 2012. Mindsets That Promote Resilience: When Students Believe That Personal Characteristics Can Be Developed Mindsets That Promote Resilience: When Students Believe That Personal Characteristics Can
Be Developed, (December 2014), 37-41. https://doi.org/10.1080/00461520.2012. 722805

Zhou, W. \& Rosini, E. 2015. Entrepreneurial Team Diversity and Performance: Toward an Integrated Model. Entrepreneurship Research Journal, 5(1), 31-60. https://doi. org/10.1515/erj-2014-0005 